\title{
Evaluation of childhood solid pseudopapillary tumors of the pancreas
}

\author{
Alper Ozcan, ${ }^{1}$ Ceyda Arslanoglu, ${ }^{2}$ Ekrem Unal, ${ }^{1}$ Turkan Patiroglu, ${ }^{1}$ Mehmet Akif Ozdemir, ${ }^{1}$ Kemal Deniz, $^{3}$ \\ Serdal Sadet Ozcan, ${ }^{4}$ Musa Karakukcu${ }^{1}$ \\ ${ }^{1}$ Department of Pediatrics, Division of Pediatric Hematology and Oncology, Erciyes University, Faculty of Medicine, Kayseri, Turkey \\ ${ }^{2}$ Department of Pediatrics, Erciyes University, Faculty of Medicine, Kayseri, Turkey \\ ${ }^{3}$ Department of Pathology, Erciyes University, Faculty of Medicine, Kayseri, Turkey \\ ${ }^{4}$ Department of Pathology, Training and Research Hospital, Kayseri, Turkey
}

\begin{abstract}
OBJECTIVE: Solid pseudopapillary tumor (SPT) of the pancreas is an extremely rare primary tumor in the pediatric age group. It has a low malignant potential and the prognosis is good if radical resection of the tumor is performed. Local recurrence and distant metastasis has only rarely been reported following incomplete resection.

METHODS: A retrospective review of the medical records of 6 patients diagnosed as SPT according to a histopathological examination at the Children's Hospital of Erciyes University School of Medicine between 2010 and 2017 was performed. Demographic characteristics, tumor localization and size, diagnostic method, immunohistochemical staining features, and medical and surgical treatments employed were recorded.

RESULTS: There were 4 girls and 2 boys with the diagnosis of SPT included in this study. The mean age of the patients was 14 years (min-max: 13-16 years). The most common presenting complaint was abdominal pain. The mass lesion was at the head of the pancreas in 3 cases (50\%) and the tail of the pancreas in the remaining 3 patients (50\%). A Whipple procedure was performed in 3 cases, a distal pancreatectomy in 1, a distal pancreatectomy plus splenectomy in 1, and a subtotal pancreatectomy in 1patient. Immunohistochemistry revealed positive staining for beta-catenin, keratin, CD56, vimentin, and CD10 in all cases.

CONCLUSION: SPT is a rarely seen pancreatic mass with low rate of malignancy. Diagnosis may be delayed due to its asymptomatic nature in most cases and a lack of descriptive symptoms. The survival rate is quite high after radical resection.

Keywords: Child; pancreas; pseudopapillary tumor.

Cite this article as: Ozcan A, Arslanoglu C, Unal E, Patiroglu T, Ozdemir MA, Deniz K. Evaluation of childhood solid pseudopapillary tumors of the pancreas. North Clin Istanb 2018;5(3):207-210.
\end{abstract}

Colid pseudopapillary tumor (SPT) is one of the rarely $\checkmark$ seen primary tumors of the pancreas. In all age groups they constitute $2-3 \%$ of all primary pancreatic tumors [1]. They are more frequently seen in the second, and third decades of life, and in female children [2]. It was firstly defined by Frantz in the year 1959, and it was termed as papillary cystic tumor, solid cystic tumor, Frantz's tumor
[3]. In the year 1996, the World Health Organization designated the term "solid pseudopapillary tumor" for this tumor [4]. It has lower malignancy potential, and its prognosis is very good after radical resection. However local recurrence, and also distant metastasis were reported following incomplete resection [5]. Its pathogenesis has not been clarified completely yet. Some authors claimed that

Received: August 15, 2017 Accepted: October 03, 2017 Online: April 18, 2018

Correspondence: Dr. Musa KARAKUKCU. Erciyes Universitesi Tıp Fakultesi, Pediatrik Hematoloji ve Onkoloji Anabilim Dali, Kayseri, Turkey.

Phone: +90532 3817120 e-mail: mkkukcu@yahoo.com

(c) Copyright 2018 by Istanbul Provincial Directorate of Health - Available online at www.northclinist.com 
this tumor has a hormonal origin, some others advocated that these tumors originate from ductal, acinar or primitive cells. Characteristically these tumors are bulky, however they are asymptomatic or have mild symptoms [6].

In this study, clinical characteristics, results of pathophysiologic, immunohistochemical analyses, and surgical treatment have been ivestigated.

\section{MATERIALS AND METHODS}

In this study the files of 6 patients who were diagnosed as SPT based on the histopathological examination of the specimen in Erciyes University Faculty of Medicine, Hospital of Children's Health and Diseases between the years 2010, and 2017 were retrospectively screened. Approval of Ethics Committee of Erciyes University Faculty of Medicine was obtained. Demographic characteristics, location, and size of the tumor, diagnostic methods, immunohistochemical staining characteristics, medical, annd surgical treatments applied were recorded. For immunohistochemical staining, beta-catenin, keratin, chromogranin, CD56, synaptophysin, vimentin, CD10, and cyclinD1 were used.

\section{RESULTS}

Six patients (4 female, and 2 male patients with a male/ female ratio of $1: 2$ ) with a mean age of 14 (min-max 13-16) years who were histopathologically diagnosed as SPT between 2010, and 2017 were included in the study. Admission complaint of $5(88 \%)$ patients was abdominal pain. Abdominal ultrasound (US) performed with the indication of hirsutismus revealed the presence of a mass which established the diagnosis of SPT. The mass lesion was localized on the head $(n=3 ; 50 \%)$, and

TABLE 1. The characteristic features of the patients in the pediatric age group followed up with the diagnosis of SPT

\begin{tabular}{|c|c|c|c|c|c|c|c|c|}
\hline Case & Age & Gender & $\begin{array}{l}\text { Admission } \\
\text { complaint }\end{array}$ & Location & Size $(\mathrm{cm})$ & $\begin{array}{l}\text { Imaging } \\
\text { modality }\end{array}$ & $\begin{array}{c}\text { Followup } \\
\text { period (months) }\end{array}$ & Treatment \\
\hline 1 & 13 & K & $\begin{array}{l}\text { Abdominal } \\
\text { pain }\end{array}$ & $\begin{array}{l}\text { Tail of the } \\
\text { pancreas }\end{array}$ & 10 & US-MRI & 43 & $\begin{array}{c}\text { Distal } \\
\text { pancreatectomy } \\
+ \text { splenectomy }\end{array}$ \\
\hline 2 & 13 & $E$ & $\begin{array}{l}\text { Abdominal } \\
\text { pain }\end{array}$ & $\begin{array}{l}\text { Tail of the } \\
\text { pancreas }\end{array}$ & 10 & US-MRI & 76 & $\begin{array}{c}\text { Distal } \\
\text { pancreatectomy }\end{array}$ \\
\hline 3 & 15 & K & $\begin{array}{l}\text { Abdominal } \\
\text { pain }\end{array}$ & $\begin{array}{l}\text { Head of the } \\
\text { pancreas }\end{array}$ & 9 & CT-MRI & 85 & Whipple surgery \\
\hline 4 & 16 & $\mathrm{~K}$ & Hirsutism & $\begin{array}{l}\text { Head of the } \\
\text { pancreas }\end{array}$ & 5 & US-MRI & 96 & Whipple surgery \\
\hline 5 & 16 & K & Abdominal pain & $\begin{array}{l}\text { Head of the } \\
\text { pancreas }\end{array}$ & 6 & US-MRI & 99 & Whipple surgery \\
\hline 6 & 11 & $E$ & Abdominal pain & $\begin{array}{l}\text { Tail of the } \\
\text { pancreas }\end{array}$ & 5 & US-CT-MRI & 30 & $\begin{array}{c}\text { Subtotal } \\
\text { pancreatectomy }\end{array}$ \\
\hline
\end{tabular}

TABLE 2. The immunohistochemical characteristics of the patients in the pediatric age group followed up with the diagnosis of SPT

\begin{tabular}{|c|c|c|c|c|c|c|c|c|c|}
\hline Case & Beta-catenin & Ceratin & Chromogranin & CD56 & Synaptophysin & Vimentin & CD10 & Cyclin D1 & NSE \\
\hline 1 & + & + & - & + & + & + & + & + & + \\
\hline 2 & + & + & + & + & + & + & + & & \\
\hline 3 & + & + & - & + & - & + & + & & \\
\hline 4 & + & + & - & + & - & + & + & & \\
\hline 5 & + & + & - & + & - & + & + & & \\
\hline 6 & + & + & - & + & + & + & + & & \\
\hline
\end{tabular}


tail $(\mathrm{n}=3 ; 50 \%)$ of the pancreas. US, and computed tomography (CT) were performed for the identification of the mass. All patients also additionally underwent magnetic resonance imaging (MRI). Median tumor diameter was $16.5(5-10) \mathrm{cm}$. Liver function tests, cholestatic, and pancreatic enzymes were within normal limits The patients were followed up for a median of 71.5 (30-96) months. We performed Whipple surgery $(n=3)$, distal pancreatectomy $(\mathrm{n}=1)$, distal pancreatectomy and splenectomy $(\mathrm{n}=1)$, and subtotal pancreatectomy $(\mathrm{n}=1)$. Complication developed in one patient, and formation of a pseudocyst was also observed (Table 1). Samples harvested from 6 patients were subjected to immunohistochemical analyses. In all patients beta- catenin, ceratin, CD56, vimentin CD 10 staining positivity was detected In one $(16.3 \%)$ patient chromogranin, and in $3(50 \%)$ patients synaptophysin positivity were detected (Table 2).

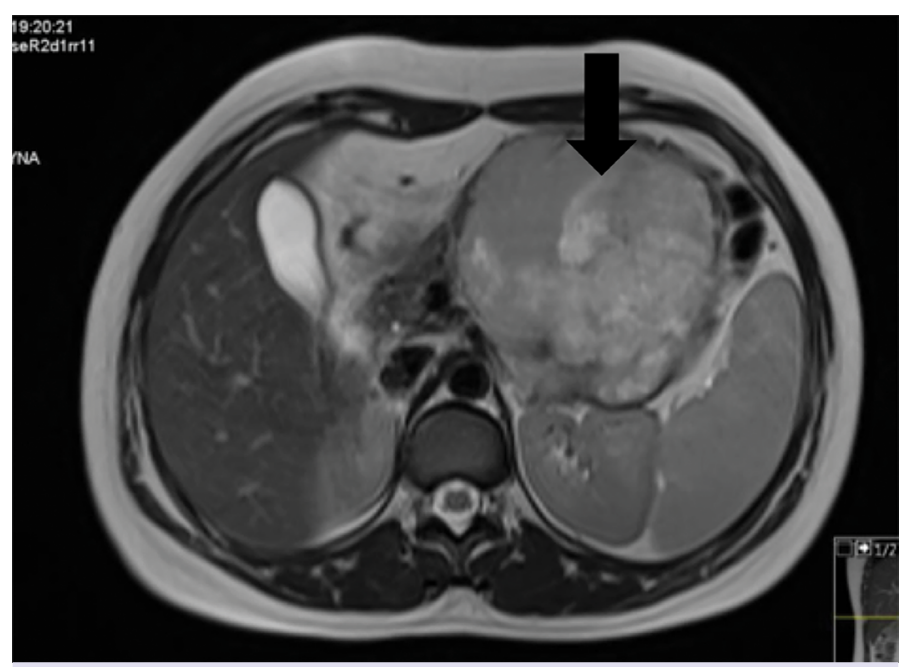

FIGURE 1. On axial T2- weighted images hyperintense heterogenous giant solid mass in the body, and tail of the pancreas.

normal limits, and consistent with the diagnosis of polycystic ovary syndrome.

In the determination of pancreatic mass lesions, US is the first-line preference because of its lower cost, and lack of radiation exposure US may aid in the determination of the association of the mass with mesenteric, and splenic vessels, and Doppler US helps us to identify intratumoral vascularization [14]. Procacci et al. estimated diagnostic accuracy of CT in pancreatic tumors with cystic component as 60 percent. Although CT plays a major role in the diagnostic evaluation of cystic lesions of pancreas, when compared with MRI, some disadvantages of CT have been reported in demonstrating tissue characteristics as bleeding, cystic degeneration, and presence of a capsule $[15,16]$. In our patients, firstly mass lesion was detected using US or CT, then MRI was used to make an initial radiological diagnosis of SPT (Fig. 1).

In children tumor is more frequently (60-70\%) localized on the head of the pancreas contrary to its location in adults, In children SPT is localized in the head of the pancreas. However in adult patients SPT is mostly (80\%) localized in the body, and the tail of the pancreas [17]. In the present study, contary to literature findings mass lesion was located in the head of the pancreas in $50 \%$, and in the tail of the pancreas also in $50 \%$ of the patients.

It has been reported that pancreatic SPT cells express exocrine, endocrine, mesenchymal, and epithelial cell markers in varying amounts [8]. SPT has a complex immune profile. In previous studies respective percentages of patients demonstrated positive staining with NSE (93\%), vievaluation of the all patients were found to be within 

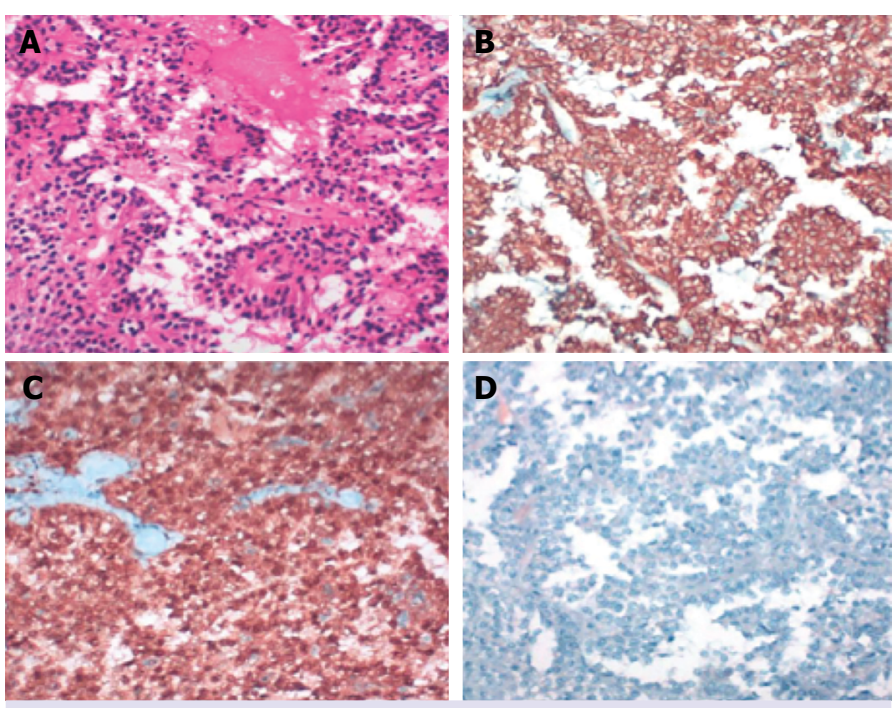

FIGURE 2. Microscopic appearance of pseudopapillary component of the tumor (A) staining with HE (B) Positive staining with vimentin (C) Nuclear, and cytoplasmic positive staining with B catenin (D) Negative staining with chromogranin.

mentin (90\%), chromogranin A, cytokeratin, and synaptophysin $[2,8]$. In another study performed with 11 pediatric patients with SPT, respective percentages of patients displayed positive staining with NSE (36\%), chromogranin A (91\%) [8]. However in the present study only one patient (16.3\%) manifested positive staining with chromogranin. In all patients, positive staining with beta-catenin, keratin, CD56, vimentin CD 10 was detected. Synaptophysin positivity was detected in 3 (50\%) patients (Fig. 2).

Surgical resection constitutes the basis of treatment. In cases of radical resection of the tumor prognosis is generally good. Long-term survival, and recurrence rates were reported as 90, and 10\%, respectively [18]. In 6 cases total surgical resection was achieved. Physical, and US examinations were maintained during follow-up period. During our average follow-up of 6 years any recurrence was not detected.

In conclusion, SPT is a rarely seen pancreatic mass with lower malignancy rates. Since it has nondescriptive characteristics, and asymptomatic course, diagnosis may be delayed. Survival rates are at a higher level when total surgical resection was performed.

Conflict of Interest: No conflict of interest was declared by the authors.

Financial Disclosure: The authors declared that this study has received no financial support.

Authorship Contributions: Concept - A.O., E.U., C.A.; Design S.S.O., A.O.; Supervision - A.O., M.K., E.U.; Materials - C.A., K.D.,
S.S.O.; Data collection \&/or processing - C.A., A.O., S.S.O., K.D.; Analysis and/or interpretation - A.O., M.K., E.U.; Writing - A.O., C.A., S.S.O.; Critical review - T.P., M.A.O.

\section{REFERENCES}

1. Sur YK, Lee JH, Kim JK, Park MJ, Kim B, Park MS, et al. Comparison of MR imaging features of solid pseudopapillary neoplasm of pancreas between male and female patients. Eur J Radiol 2015;84:2065-70.

2. Branco C, Vilaça S, Falcão J. Solid pseudopapillary neoplasm-Case report of a rare pancreatic tumor. Int J Surg Case Rep 2017;33:148-50.

3. Divarc1 E, Dökümcü Z, Çetingül N, Nart D, Barbet FY, Ergün O, et al. Radical resection of the pancreas should not always be necessary in the surgical management of pancreatic solid pseudopapillary tumor in children. Turk J Gastroenterol 2017;28:214-8. [CrossRef]

4. Klöppel G, Solcia E, Longnecker DS, Capella C, Sobin L. Histological Typing of Tumours of the Exocrine Pancreas. 2nd ed. Springer-Verlag Berlin Heidelberg; 1996. [CrossRef]

5. Morita K, Urushihara N, Fukumoto K, Miyano G, Yamoto M, Nouso $\mathrm{H}$, et al. Solid pseudopapillary tumor of the pancreas in children: surgical intervention strategies based on pathological findings. Pediatr Surg Int 2014;30:253-7. [CrossRef]

6. Spătaru RI, Enculescu A, Popoiu MC. Gruber-Frantz tumor: a very rare pathological condition in children. Rom J Morphol Embryol 2014;55:1497-501.

7. Rebhandl W, Felberbauer FX, Puig S, Paya K, Hochschorner S, Barlan $\mathrm{M}$, et al. Solid-pseudopapillary tumor of the pancreas (Frantz tumor) in children: report of four cases and review of the literature. J Surg Oncol 2001;76:289-96. [CrossRef]

8. Park JY, Kim SG, Park J. Solid pseudopapillary tumor of the pancreas in children: 15-year experience at a single institution with assays using an immunohistochemical panel. Ann Surg Treat Res 2014;86:130-5.

9. Veras E, Mao TL, Ayhan A, Ueda S, Lai H, Hayran M, et al. Cystic and adenofibromatous clear cell carcinomas of the ovary: distinctive tumors that differ in their pathogenesis and behavior: a clinicopathologic analysis of 122 cases. Am J Surg Pathol 2009;33:844-53. [CrossRef]

10. Jung SE, Kim DY, Park KW, Lee SC, Jang JJ, Kim WK. Solid and papillary epithelial neoplasm of the pancreas in children. World J Surg 1999;23:233-6. [CrossRef]

11. Parelkar SV, Oak SN, Kapadnis SP, Sanghvi BV, Joshi PB, Sathe P, et al. Solid pseudo papillary tumor of the pancreas: An unusual tumor in children. J Indian Assoc Pediatr Surg 2013;18:38-40. [CrossRef]

12. Erkılıç S, Özsaraç C, Güldür E. Solid-Pseudopapillary Neoplasm of Pancreas: A Case report. Turk Patoloji Derg 2003;19:3-4.

13. Raffel A, Cupisti K, Krausch M, Braunstein S, Tröbs B, Goretzki PE, et al. Therapeutic strategy of papillary cystic and solid neoplasm (PCSN): a rare non-endocrine tumor of the pancreas in children. Surg Oncol 2004;13:1-6. [CrossRef]

14. Shet NS, Cole BL, Iyer RS. Imaging of pediatric pancreatic neoplasms with radiologic-histopathologic correlation. AJR Am J Roentgenol 2014;202:1337-48. [CrossRef]

15. Salvia R, Festa L, Butturini G, Tonsi A, Sartori N, Biasutti C, et al. Pancreatic cystic tumors. Minerva Chir 2004;59:185-207.

16. Cantisani V, Mortele KJ, Levy A, Glickman JN, Ricci P, Passariello R, et al. MR imaging features of solid pseudopapillary tumor of the pancreas in adult and pediatric patients. AJR Am J Roentgenol 2003;181:395-401.

17. Escobar MA, Bond BJ, Schopp J. Solid pseudopapillary tumour (Frantz's tumour) of the pancreas in childhood. BMJ Case Rep 2014;2014. pii: bcr2013200889.

18. Çolak B, Çakır M, Çolak MH. Solid pseudopapillary tumor of the pancreas: A Case Report. Genel Tip Derg 2013;23:23-5. 